DOI: http://doi.org/10.21698/simi.2018.fp38

\title{
WATER QUALITY ASSESSMENT USING PHYSICAL-CHEMICAL PARAMETERS OF THE DANUBE RIVER (DELTAIC AREA) INCLUDING RAZIM AND GOLOVITA LAKES, ROMANIA
}

Irina Catianis, Gabriel Iordache, Dumitru Grosu, Marian Malageanu, Iulian Pojar, Ana Bianca Pavel

National Institute of Marine Geology and Geoecology - GeoEcoMar, Bucharest, 23 - 25

Dimitrie Onciul Street, 024053, Bucharest, irina.catianis@geoecomar.ro, Romania

\begin{abstract}
The present study assessed the spatial water quality variation of physical and chemical variables. The water quality data were collected during May 2018 from several sampling stations distributed between Ceatal Izmail and Sf. Gheorghe branch and up to the Dunavat Canal, as well as Razim and Golovita lakes. The sampling stations were selected on the basis of their contamination susceptibility, i.e., the station located along the above-mentioned sector of the Danube River were tended to be more impaired by the human related activities. Instead, the stations downstream to the Danube River (the lower course - deltaic area), i.e., Razim and Golovita lakes were supposed to be less impaired by the urban and rural contamination. The investigated sites are of particular interest since they belong to the Danube Delta Biosphere Reserve (DDBR). The following water quality parameters were measured: depth $(\mathrm{m})$, temperature $\left({ }^{\circ} \mathrm{C}\right), \mathrm{pH}$ (units), dissolved oxygen content (mg/l), electrical conductivity $(\mu \mathrm{S} / \mathrm{cm})$, total dissolved solids $(\mathrm{mg} / \mathrm{l})$, sulphates (mg/l), nitrite-nitrogen (mg/l), nitrate-nitrogen $(\mathrm{mg} / \mathrm{l})$, orthophosphates (mg/l), chlorophyll "a” ( $\mu \mathrm{g} / \mathrm{l})$, turbidity (NTU), total suspended solids (mg/l), Secchi visibility $(\mathrm{m})$, silica content $(\mathrm{mg} / \mathrm{l})$ etc. Overall, the results indicated that some variables presented comparable values that have not exceeded those limits recommended by the reference standard. Instead, the fall in the quality of water (any abnormal values encountered in a few situations) may be related to a wide range of local natural environmental circumstances, as well as anthropic factors. The outcomes obtained from the present study shall be useful in the future environmental assessment of the aquatic ecosystems in DDBR area.
\end{abstract}

Keywords: ecosystems, evaluation, physical-chemical parameters, transitional waters, water quality

\section{Introduction}

Generally speaking, the water quality is fundamental for life, basic human needs and environmental issues sustaining ecological processes that support the development of plant and animal communities. Surface water resources are vulnerable to chemical, physical and microbiological contamination through natural and/or 


\section{INTERNATIONAL SYMPOSIUM "THE ENVIRONMENT AND THE INDUSTRY", SIMI 2018, PROCEEDINGS BOOK}

human-related activities. There are many sources that might cause water stress and quality impairment, but most are one of physical and chemical categories such as land disposal of sewage effluents, sludge and solid waste, septic tank effluent, urban runoff and agricultural, mining and industrial practices (Close et al 2008). The stability of aquatic environments, including transitional waters as coastal lagoons, and their variations under contemporaneous conditions (effects of natural and anthropogenic stressors) are settled by the Water Framework Directive (WFD 2000/60/EC). This ordinance requires the achievement or maintenance of a good ecological status in order to provide for a sustainable future for aquatic systems and their habitats. The coastal wetlands are very important vulnerable ecosystems assuring suitable environment for a large community of plants and animals. Subsequently, they are also centers of economic activities as they ensure the environment for fishery exploitation, farming practices, reed exploitation, water tourism etc. The lagoons have particular characteristics which include the ecological, morphological and hydrodynamic aspects. Also known as transitional environments, they act as receptors and diluters of several inputs of substances (hazardous substances, nutrients) and other water pollutants originating from a variety of sources, both natural and artificial. The water circulation in a lagoon is rather limited to be able to withstand the ecosystem changes in water quality so that they become susceptible to anthropogenic pressures (Johnson et al 2007). Some examples of anthropogenic pressures that may have a strong impact on coastal ecosystems are: land-use change, freshwater withdrawal from ground and surface water sources, sedimentation, point and nonpoint water pollution, shoreline hardening, and overfishing (U.S. EPA 2007). Evaluation of the water quality in the Razim-Sinoie Lagoon Complex is required for surveying of ecosystem features and dynamic processes that support them. In this lagoon system consists of several large brackish lagoons located in the southeastern part of Romania, the attainment of a good ecological status is interfered by several natural and anthropogenic factors. In recent years, there have been many studies about the effects of the natural and anthropogenic changes to geomorphological environments and ecosystems of the Razim-Sinoie Lagoon Complex (Panin 1974, Panin 1996, Romanescu 2009, Vespremeanu et al 2013). The lagoon system has undergone through gradual changes as a result of increasing man-made pressure that led to adverse consequences, regarding the residence time, eutrophication and salinity of the lagoon system (Dinu et al 2015). The artificial introduction of fresh water negatively affected the salinity of the water system in the lagoon complex (Stanica 2012) with repercussions on the levels of fauna and flora density. The differences in environmental state of Razim-Sinoie Lagoon Complex as a response to the shifts in salinity regime distinctly affected the local species diversity, abundance and trophic status (Teodorescu-Leonte et al 1956, Teodorescu-Leonte 1977). Likewise, human interference through the medium of different artificial structures (i.e., system of dams and dikes, drainage systems, opening/closing of sluice-gate) designed to control natural processes are among the most common cause of coastal erosion (Spataru 1990, Vespremeanu-Stroe et al 2007). The present study assessed the 


\section{INTERNATIONAL SYMPOSIUM "THE ENVIRONMENT AND THE INDUSTRY", SIMI 2018, PROCEEDINGS BOOK}

spatial water quality variation of physical and chemical variables. The aim was to identify the main potential water stress and deteriorating water quality sources in the Razim and Golovita lakes, and in a particular sector of its major connection Danube River - the main supply of water and sediment. The investigated sites are of particular interest since they belong to the DDBR. The outstanding universal value of the DDBR has been recognized (e.g., Romanian Government Decision no. 983/1990) through the inclusion within an international network of biosphere reserves. The purpose of this study is to reveal the extent to which the natural factors and/or human related activities performed around the investigated lakes has impacted on its physical-chemical parameters. The environmental quality of the investigated sites is greatly influenced by many variables. For instance, expected shifts in physical-chemical characteristics of these relatively shallow waters (i.e., Razim L. and Golovita L.) range from changes in the freshwater inputs (connections with Sf. Gheorghe branch), the local climatic conditions (wind stress, waves, precipitation to evaporation balance), sedimentation rates and erosion processes etc.

In addition to the water quality assessment, a preliminary mapping of emergent aquatic vegetation existing in the Razim Lake i.e., in the southeastern part of it (Holbina Gulf), was performed to estimate the evolution of aquatic vegetation in recent years. The importance of topo-geodesic mapping and monitoring of the stability of the Danube Delta's riparian associations is imperative because they are the main habitat for the fish fauna and other wildlife species. Aquatic plants play a decisive role in the absorption of the nutrients from eutrophic waters, the reduction of heavy metal concentrations and the sediment retention. Several studies have found that the Phragmites australis (common reed), play an important role in the removal of zinc in waste water. The quantity and the composition of aquatic plants has a great influence on water quality, affecting temperature and light conditions, carbon dioxide concentration, organic matter quantity and water movements. Aquatic plants can indirectly diminish water turbulence by preventing its movements and thus preventing sedimentation disturbances. It is known that aquatic plants reduce the growth potential of phytoplankton by decreasing the availability of nutrients (Huhta 2009). The increased amount of aquatic plants decreases the flow of nutrients from the sediment and therefore the amount of nutrients in the water. It also removes nitrogen from the water ecosystem.

\section{Materials and Methods}

Study Area and Sampling Sites

The Razim and Golovita lakes belong to the Razim-Sinoie lagoon complex, which is situated to the south of the Danube Delta and on the western coast of the Black Sea (Figure 1a). The lagoon complex comprises the only brackish lakes in Romania that are connected both to the Danube River and to the Black Sea (Figure 1b). The lagoon's total drainage area is $1145 \mathrm{~km}^{2}$ of which the lagoons and limans expand approximately $863 \mathrm{~km}^{2}$. Razim Lake is the largest freshwater lagoon in Romania, with an area of $415 \mathrm{~km}^{2}$ and a maximum depth of $3.5 \mathrm{~m}$. The surface area of Golovita Lake is $118.7 \mathrm{~km}^{2}$. The freshwater inflow to the lagoon is facilitated by the 


\section{INTERNATIONAL SYMPOSIUM "THE ENVIRONMENT AND THE INDUSTRY", SIMI 2018, PROCEEDINGS BOOK}

Sf. Gheorghe branch via Dunavat and Dranov canals, where receives a contribution coming from the Danube River. The environmental impairment trend of the RazimSinoie Lagoon Complex began in the last decades as a result of different hydro technical works (e.g., levees, dikes, cut-offs, canalization) performed for the development of irrigation systems and the fishery exploitation potential of its water bodies. The field measurements were carried out in the investigated perimeters on RV "Istros” owned by the National Institute of Marine Geology and Geoecology GeoEcoMar, Romania. The water quality data were collected during May 2018 from several sampling stations distributed along a sector of the Danube River (i.e., the lower course - deltaic area), namely between Ceatal Izmail and Sf. Gheorghe branch and up to the Dunavat Canal, as well as Razim and Golovita lakes (Figure 1c). The sampling stations were selected on the basis of their contamination susceptibility, i.e., the station located along the above-mentioned sector of the Danube River were tended to be more impaired by the human related activities. Instead, the stations downstream to the Danube River (the lower course - deltaic area), i.e., Razim and Golovita lakes were supposed to be less impaired by the urban and rural contamination.

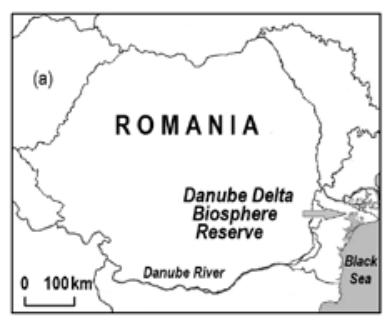

Figure 1. The geographical setting of the study area in Romania (a), within the Danube Delta Biosphere Reserve (b), and distribution of sampling sites (c) along a sector of the Danube River (the lower course - deltaic area), between Ceatal Izmail and Sf. Gheorghe branch and up to the Dunavat Canal, and in Razim and Golovita lakes.

The water samples were gathered from surface $(0.5 \mathrm{~m})$ using Niskin Water Sampler (Figure 2). In situ parameters such as depth (m), temperature $\left({ }^{\circ} \mathrm{C}\right), \mathrm{pH}$ (units), dissolved oxygen content $(\mathrm{mg} / \mathrm{l})$, electrical conductivity $(\mu \mathrm{S} / \mathrm{cm})$, turbidity (NTU) along with water transparency/visibility (VDS) using a Secchi disc (25 cm diameter) were measured at the sampling spots aboard the RV "Istros". The other parameters, i.e., nitrite-nitrogen $(\mathrm{mg} / \mathrm{l})$, nitrate-nitrogen $(\mathrm{mg} / \mathrm{l})$, orthophosphates $(\mathrm{mg} / \mathrm{l})$, total dissolved solids (mg/l), sulphates (mg/l), total suspended solids (mg/l), chlorophyll "a” ( $\mu \mathrm{g} / \mathrm{l})$, silica content (mg/l) etc., were analyzed ex situ at different laboratories. The values of the above parameters were acquired with WTW Multiline P4 


\section{INTERNATIONAL SYMPOSIUM "THE ENVIRONMENT AND THE INDUSTRY", SIMI 2018, PROCEEDINGS BOOK}

Multiparameter (Figure 2), (e.g., temperature, $\mathrm{pH}$, dissolved oxygen, conductivity, total dissolved solids, oxidation-reduction potential), HACH $2100 \mathrm{Q}$ (e.g., turbidity), and HACH 5000 - UV-Vis-Spectrophotometer (e.g., nitrites, nitrates, phosphates, sulphates). The obtained results were related to national standard guideline value for surface water quality (Order No. 161/2006), as well as other available environmental standards for variables as total dissolved solids (DeZuane 1997), turbidity (Romanian Standard - STAS 6323 - 88), total suspended solids (ANZECC 2000 Guidelines), oxidation-reduction potential (Sigg 2000) and the silica content (http://www.freedrinkingwater.com/water_quality).

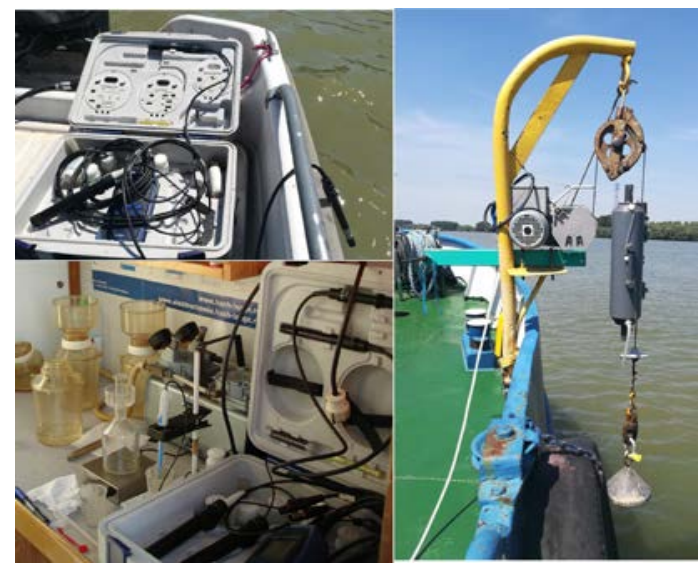

Figure 2. Collecting and measuring in situ and ex situ water quality parameters

Moreover, different topo-geodesic measurements were performed on the southeastern part of the Razim Lake (i.e., Holbina Bay) for preliminary mapping of emergent aquatic vegetation changes during the last years. Wetland plants as reeds and marsh grasses may provide a natural, efficient and sustainable filtration system, thus contributing to the state of water quality. High-precision GPS measurements have been made to topo-geodesic mapping of the vegetation, that have highlighted the limit contour of the vegetation permeated in two areas of the Holbina Bay (Razim L.): the south-western part, i.e., Cosburunu Mare (about $4.4 \mathrm{~km}$ ), and the eastern part of the bay (about $3 \mathrm{~km}$ ) up to near the mouth of the Dranov Canal.

\section{Results and Discussion}

This research investigation covered the first interval of May 2018 and took place at 13 stations in the Danube River branches and rivulets, as well as 25 stations at Razim L., and respectively, 15 stations at Golovita L. (Figure 1c). The control sections located along the sector of the Danube River (the lower course - deltaic area) are specified further on: Ceatal Izmail - Mm 43.5 (DD18-02 station), Chilia 


\section{INTERNATIONAL SYMPOSIUM "THE ENVIRONMENT AND THE INDUSTRY", SIMI 2018, PROCEEDINGS BOOK}

Branch-km 115.5 (DD18-05), Tulcea Branch - Mm 42.5 (DD18-08), Ceatal Sf. Gheorghe- km 108 (DD18-11), Tulcea Branch - Mm 34 (DD18-14), Sulina Branch - Mm 33 (DD18-17), Sf. Gheorghe Branch - km 85 - downstream of Mahmudia village (DD18-20), Sf. Gheorghe Branch - km 63 - downstream of Murighiol village (DD18-24), Old Danube Meander - km 65 (DD18-27), Sf. Gheorghe Branch - km 59 (DD18-30), Sf. Gheorghe Branch - km 57+500 (DD18-31), Sf. Gheorghe Branch - the first cut-off meander (DD18-32) and Dunavat Canal (DD1837).

In general, the results of the investigation showed uniform environmental conditions (i.e., Low local fluctuations), the variables appear quite plain, with nearly regular distribution. A synthetic presentation will be made in the following. The sampling period was characterized by the oscillating thermal regime, sunny days respectively, heavy rain days and strong winds with gusts, undeveloped underwater vegetation and a higher mean value of the river water level $(295.23 \mathrm{~cm})$ registered in May 2018. Climate factors that act on the water surface temperatures measured during the investigation period showed uniform trends with insignificant fluctuations in the measured values. Water temperature $(\mathrm{T})$ is one of the most important physical characteristics of aquatic ecosystems and influences a number of water quality parameters (Chapman 1996). The minimum $\mathrm{T}$ at all stations situated on the control section of the Danube River was measured at Tulcea Branch-Mm $42.5\left(20^{\circ} \mathrm{C}\right)$, while the maximum $\mathrm{T}$ was registered at Dunavat Canal $\left(21.9^{\circ} \mathrm{C}\right)$. Similarly, the mean value of water $\mathrm{T}$ was consistent with the normal seasonal variations for the period of May, e.g., Razim L. $\left(20.28^{\circ} \mathrm{C}\right)$ and Golovita L. $\left(20.06^{\circ} \mathrm{C}\right)$.

Dissolved oxygen (DO) is one of the important parameters in water quality assessment and reflects the biological and physical processes predominating in the water. The dissolved oxygen is an important factor for aquatic life and the chemical characteristics of the environment (Chapman 1996). In the present study, DO concentration among the control section of the Danube River, as well as investigated lakes, showed little variation. The measurements of DO concentration revealed that all investigated water samples were well-aerated, with dissolved oxygen concentrations in excess of $5 \mathrm{mg} / \mathrm{l}$. A minimum DO concentration of $5 \mathrm{mg} / \mathrm{l}$ is recommended to adequately support aquatic life (www.niwa.co.nz/ourscience/freshwater/tools/kaitiaki_tools/impacts/dissolved-oxygen). The variations recorded are roughly similar. In the control sections of the Danube River, the highest value of DO concentration was encountered in Dunavat Canal $(9.17 \mathrm{mg} / \mathrm{l})$, while the lowest was recorded in Sf. Gheorghe Branch - km 85 - downstream of Mahmudia village $(7.58 \mathrm{mg} / \mathrm{l})$. As well, the mean value of DO concentration was higher than 5 $\mathrm{mg} / \mathrm{l}$, also in Razim L. (9.02 mg/l), and Golovita L (9.35 mg/l). The results showed almost the same trend of the average concentration of DO content, regardless of the sample station localization, i.e., the Danube River waters, as well as the lakes.

In agreement with the USEPA (1980), accepted water quality criteria specify a $\mathrm{pH}$ of less than 6.5 units may be harmful to many species of fish. Therefore, the $\mathrm{pH}$ range of 6.5-9.0 units would be suitable for the protection of aquatic habitats. In this study, the measured water samples generally ranged from a normal $\mathrm{pH}$ to a slightly 


\section{INTERNATIONAL SYMPOSIUM "THE ENVIRONMENT AND THE INDUSTRY", SIMI 2018, PROCEEDINGS BOOK}

alkaline $\mathrm{pH}$ in the majority of sampling sites. The $\mathrm{pH}$ of investigated water samples compared favorably with the national water quality standard. So, in the control sections of the Danube River, the lowest value was measured in Sf. Gheorghe Branch - km 85 - downstream of Mahmudia (7.67) and the highest value was observed in Old Danube Meander - km 65 (8.04). The $\mathrm{pH}$ values did not vary much between the control sections of the Danube River. The water reaction $(\mathrm{pH})$ tested in the water of the investigated lakes is in the $\mathrm{pH}$ range with normal-slightly alkaline mean values, such as Razim L. (7.82) and L. Golovita (7.99). The results showed that $\mathrm{pH}$ is almost similar in the Danube River waters, as well as in the lakes.

Nitrates and nitrites are the most common inorganic nitrogen compounds in the environment, and are present in waters, soils, foodstuffs and biota. The phosphates represent a form of the element phosphorus that is a fundamental support for living organisms. If the nutrients exceed certain limit concentrations are potentially dangerous substances. The increasing levels of phosphates and nitrates can have a detrimental effect on the ecological balance of rivers and lakes, and can cause harm to human health (Chapman 1996). In the present study, nitrate-nitrogen $\left(\mathrm{N}-\mathrm{NO}_{3}{ }^{-}\right)$ content tested among the control section of the Danube River, as well as investigated lakes, showed little variation. The $\mathrm{N}_{-} \mathrm{NO}_{3}{ }^{-}$levels showed very low values that are below the limit parameter corresponding to Class I of water quality (high status), (Order 161/2006). Instead, it was noticed that the nitrite-nitrogen (N$\mathrm{NO}_{2}{ }^{-}$) content, examined among the control section of the Danube River, as well as investigated lakes, showed some little variation. Therefore, it was noticed that the limit of the maximum allowable content corresponding to Class I was slightly attained or exceeded in some samples taken from: Tulcea Branch - Mm 42.5 (0.019 mg/l), Ceatal Sf. Gheorghe- km 108 (0.012 mg/l), Tulcea Branch - Mm 34 (0.01 mg/l), Sulina Branch - Mm 33 (0.011 mg/l), Sf. Gheorghe Branch - km 85 downstream of Mahmudia village (0.011 mg/l), Sf. Gheorghe Branch - km 63 downstream of Murighiol village $(0.019 \mathrm{mg} / \mathrm{l})$, Old Danube Meander - $\mathrm{km} 65$ (0.016 mg/l), Sf. Gheorghe Branch - km 59 (0.017 mg/l), Sf. Gheorghe Branch -

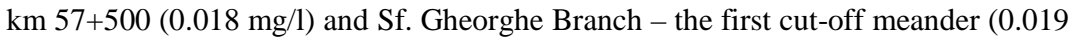
$\mathrm{mg} / \mathrm{l})$. The $\mathrm{N}-\mathrm{NO}_{2}{ }^{-}$content also presented a range of variation in the investigated lakes, as Razim L. (0.005 $-0.015 \mathrm{mg} / \mathrm{l}$, mean $=0.00975 \mathrm{mg} / \mathrm{l})$ and Golovita L.


obtained in the present study showed a range of variation, so that, the lowest value of this parameter was recorded at Ceatal Sf. Gheorghe - km 108 (0.073 mg/l), while the highest was measured at Sf. Gheorghe Branch - km 59 (1.953 mg/l). It has been noticed that the limits of the maximum allowable content specified in the reference standard (Order 161/2006) have been exceeded, covering more or less, almost all the categories characteristic of the five water quality classes (high, good, moderate, poor and bad), as follows: Chilia Branch-km 115.5 (0.303 mg/l), Tulcea Branch - Mm 42.5 (1.66 mg/l), Ceatal Sf. Gheorghe- km 108 (0.073 mg/l), Tulcea Branch - Mm 34 (1.65 mg/l), Sulina Branch - Mm 33 (1.57 mg/l), Sf. Gheorghe Branch - km 85 downstream of Mahmudia village (1.8 mg/l), Old Danube Meander - km 65 (1.853 mg/l), Sf. Gheorghe Branch - km 59 (1.953 mg/l), and Sf. Gheorghe Branch - km 


\section{INTERNATIONAL SYMPOSIUM "THE ENVIRONMENT AND THE INDUSTRY", SIMI 2018, PROCEEDINGS BOOK}

$57+500(0.103 \mathrm{mg} / \mathrm{l})$. A similar situation was also found in the investigated lakes,


$\mathrm{mg} / \mathrm{l})$ and Golovita L. (0.0366 - $1.816 \mathrm{mg} / \mathrm{l}$, mean = $1.13287 \mathrm{mg} / \mathrm{l})$. The levels of chlorophyll "a" concentration measured in some control sections of the Danube River, including the investigated lakes varies widely between $1.24-45.35 \mu \mathrm{g} / \mathrm{l}$ and a mean of $14.60 \mu \mathrm{g} / \mathrm{l}$. As a result, it was observed that some of the tested samples showed values that exceeded the limit corresponding to Class I (L. Razim - 26.86 $\mu \mathrm{g} / \mathrm{l}$, L. Golovita - $39.90 \mu \mathrm{g} / \mathrm{l}$ and Gura Portitei - $45.35 \mu \mathrm{g} / \mathrm{l})$. Presence of silicate in aquatic environments is very important for growth of group of microorganisms as diatoms (Egge \& Aksnes 1992). Based on the silica content in natural waters (www.freedrinkingwater.com) that specify values between $5-25 \mathrm{mg} / \mathrm{l}$, the majority of the investigated water samples showed lower silica content. Therefore, the highest value was identified at Old Danube Meander - km 65 (7.74 mg/l), while the lowest was recorded at Chilia Branch-km 115.5 (2.76 mg/l). The distribution of $\mathrm{SiO}_{2}$ concentration in water samples investigated in lakes had the following values: Razim L. $(0.05-3.31 \mathrm{mg} / \mathrm{l}$, mean $=0.57 \mathrm{mg} / \mathrm{l})$ and Golovita L. $(0.075-0.6975$ $\mathrm{mg} / \mathrm{l}$, mean $=0.3041 \mathrm{mg} / \mathrm{l})$.

According to imposed limit sets of national standard (Order 161/2006), the conductivity (EC) values determined in water samples among the control section of the Danube River, were at normal and low levels. For example, the lowest value was obtained at Sf. Gheorghe Branch - km 85 - downstream of Mahmudia village (382 $\mu \mathrm{S} / \mathrm{cm}$ ), while the highest value was obtained at Old Danube Meander - km 65 (397 $\mu \mathrm{S} / \mathrm{cm})$. The obtained values do not exceed the limit imposed by the current legislation, corresponding to Class I. The values of the EC level recorded in Razim L. showed values ranging from a relatively wide range $(396-612 \mu \mathrm{S} / \mathrm{cm}$, mean $=481$ $\mu \mathrm{S} / \mathrm{cm})$, values that exceeded the limit corresponding to Class I. Slightly increased levels of electrical conductivity recorded in Golovita L. were also noted, so they fall within a relatively wide range $(45-780 \mu \mathrm{S} / \mathrm{cm}$, mean $=592.4 \mu \mathrm{S} / \mathrm{cm})$, values that exceeded the limit corresponding to Class I and II.

Natural waters have a broad range of total dissolved solids (TDS) that may come from natural sources, sewage, urban and agricultural run-off, and industrial wastewater. Concentrations of TDS from natural sources have been found to vary from less than $30 \mathrm{mg} / \mathrm{l}$ to as much as $6000 \mathrm{mg} / \mathrm{l}$ (WHO/UNEP GEMS 1989), depending on the solubility's of minerals in different geological regions. At most, freshwater can have $2000 \mathrm{mg} / \mathrm{l}$ of total dissolved solids and most sources should have much less than that (US-EPA 2009). Several environmental standards that regulate water quality consider that TDS values in lakes and streams are typically found to be in the range of 50 to $250 \mathrm{mg} / \mathrm{L}$. In the present study, the variation in total dissolved solids (TDS) content trend is similar to EC, since the TDS measurements are derived from conductivity. According to the above-mentioned limits, the TDS values determined in the investigated samples were generally at normal and low levels.

The sulfate $\left(\mathrm{SO}_{4}{ }^{2-}\right)$ content did not show any significant variations among the measured water samples. According to national standard limits (Order 161/2006), 


\section{INTERNATIONAL SYMPOSIUM "THE ENVIRONMENT AND THE INDUSTRY", SIMI 2018, PROCEEDINGS BOOK}

the investigated samples could be categorized below the limit corresponding to Class I. According to these limits, it was noticed that the lowest value was obtained at Sf. Gheorghe Branch - km 59 (26 mg/l), while the highest was recorded at Chilia Branch-km 115.5 (35 mg/l). Similar values have been reached in the investigated lakes as Razim L. (28-52 mg/l, mean = 36,125 mg/l) and Golovita L. (37 - 46 mg/l, mean $=42 \mathrm{mg} / \mathrm{l}$ ). Mostly, in accordance with the results obtained for the salinity parameters e.g., EC, TDS and $\mathrm{SO}_{4}{ }^{2-}$ levels, the water samples investigated in lakes showed freshwater features.

The results of water analyses for turbidity (NTU units) revealed that some values above the maximum allowable content were remarked in most of the samples. These values were related to STAS 6323-88, which stipulates 5 NTU - admitted values, respectively $10 \mathrm{NTU}$ - exceptionally admitted values. As regards the control section of the Danube River, the highest value was met at Sf. Gheorghe Branch - km 59 (30.2 NTU), while the lowest was met at Old Danube Meander - km 65 (5.87 NTU). The turbidity values measured in water samples gathered from lakes varied in a relatively wide range with high values, such as: Razim L. (3.33 - 56.9 NTU, mean = 27.92 NTU) and Golovita L. (10.9-105 NTU, mean = 49.68 NTU)

The concentration level of TSS (total suspended solids) showed a number of variations found in the control sections on the Danube. The highest value was encountered at the Sf. Gheorghe Branch - the first cut-off meander (32 mg/l), while the lowest was found at Old Danube Meander - km 65 (8 mg/l). The results have been compared to the ANZECC 2000 Guideline standard (which provides values of $<40 \mathrm{mg} / \mathrm{l}$-acceptable levels of TSS in the freshwater environment, and, respectively $<10$-acceptable levels of TSS in the marine environment). The distribution of TSS concentration in water samples investigated in lakes has the following values: Razim L. $(7-62 \mathrm{mg} / \mathrm{l}$, mean = $35.9 \mathrm{mg} / \mathrm{l})$ and Golovita L. $(8-73 \mathrm{mg} / \mathrm{l}$, mean $=49.6 \mathrm{mg} / \mathrm{l})$. Significantly increased TSS levels above $40 \mathrm{mg} / \mathrm{l}$ have been noted, largely from the water samples tested from the two lakes.

The values of Secchi transparency $(m)$ were ranged in the control sections of the Danube. The highest value was encountered at Old Danube Meander - km 65 (1,3 $\mathrm{m})$, while the lowest $(0,5 \mathrm{~m})$ was measured at several stations such as: Ceatal Izmail - Mm 43.5, Tulcea Branch - Mm 42.5, Ceatal Sf. Gheorghe- km 108, Tulcea Branch - Mm 34 and Sulina Branch - Mm 33. In. Razim L the transparency was registered in a range of $0.2-1.3 \mathrm{~m}$, mean $=0.5 \mathrm{~m}$, and in Golovita L. it ranged between $0.2-0.5 \mathrm{~m}$, mean $=0.27 \mathrm{~m}$. Regarding the trophic status of lakes, the following situations are illustrated, based on the OECD, (OECD 1982) system: if Secchi disc depth is between 0.8 and $1.5 \mathrm{~m}$, the lake is eutrophic; if it is between 1.4 and $2.4 \mathrm{~m}$, the lake is mesotrophic and if it is between 3.6 and $5.9 \mathrm{~m}$, the lake is oligotrophic (Ryding \& Rast 1989).

The oxidation-reduction potential (ORP) showed little variation at all sampling stations. The obtained results were within the normal range of variation for natural waters (-500 mV + $700 \mathrm{mV})$ (Sigg 2000).

Synthesizing, the values recorded for the physical-chemical parameters in the present study are generally comparable with other previous investigations acquired 


\section{INTERNATIONAL SYMPOSIUM "THE ENVIRONMENT AND THE INDUSTRY", SIMI 2018, PROCEEDINGS BOOK}

at different water bodies from the DDBR area (Radan et al 2000, Dimitriu et al 2008, Munteanu et al 2012).

The various environmental conditions existing in the Danube Delta have led to the development of rich and diversified vegetation. The most common unit of the landscape of the DDBR is represented by the common reed habitats covering approximately 199,600 ha, of which the mono-dominant reed beds totalize approximately 117,000 ha (Hanganu et al 2002). The distribution of aquatic vegetation is influenced by anthropogenic or natural factors i.e., seasons, frequency of floods, erosion, accumulation etc. The mapping of emergent aquatic vegetation is important and necessary to observe its evolution in the deltaic area and the changes occurring in the aquatic ecosystems. It is also important to know, map and monitor floating reed islets in the Danube Delta. They can be fixed or movable under the action of waves or currents. Floating reed islets dynamics is absolutely necessary to be known because these formations by their movement can partially or completely close some channels may endanger navigation on lakes etc.

Floating reed islets formations also have an impact on water quality and biodiversity. So, under beneath of large stretches, the aquatic life water quality resources are improper because the sun's light cannot penetrate, the aeration is deficient, the $\mathrm{pH}$ of the water and the amount of oxygen is very low (Banu \& Rudescu 1957). As a result, drastic decrease of biodiversity in these areas may occur (Doroftei \& Covaliov 2013).

After data processing few interesting findings were noticed, highlighting the current limit expansion of emergent vegetation along lake shores, as well as its dynamics in the last years. Three periods were selected for shaping the vegetation: 2006, 2013 and 2018, based on the data available in the portfolio. A first finding is the tendency of expansion of emergent vegetation along the lake, specifically in the Cosburunu Mare sector. These changes in emergent vegetation boundaries could be explained by the positioning of each lakeshore sector in the predominant wind direction and, implicitly, wave action. In the above-mentioned area, but on the inner side of the Holbina Bay, the tendency of wind and climate-induced vegetation changes in the lake show a retraction phenomenon of the vegetation and shoreline, too. This may be due to the direct exposure of the wave action generated by the winds blowing in the area, predominantly in the north-eastern sector. Wave movements act on the existing vegetation of the lakeshores, implicitly on the unconsolidated underwater sediment, producing under certain conditions the dislocations of some parts of the vegetation. In this way reed islets begin to evolve floating freely on the surface of the water under the influence of the wind and currents. These dislocations may affect the structure of the habitats established in these favorable areas of wildlife environment. Concerning the second area where topo-geodetic measurements were made i.e., Holbina Bay, near the mouth of the Dranov Canal, no significant changes were found about the limit of the vegetation. It can be assumed that the vegetation on the eastern lakeshore of the Holbina bay has a relative stability. An explanation for this phenomenon could be found in the fact that this part of the bay is protected from the action of waves generated by winds blowing from the north-eastern sector. 


\section{INTERNATIONAL SYMPOSIUM "THE ENVIRONMENT AND THE INDUSTRY", SIMI 2018, PROCEEDINGS BOOK}

\section{Conclusions}

According to the results, some variables (e.g., temperature, $\mathrm{pH}$, dissolved oxygen content, electrical conductivity, total dissolved solids, nitrate-nitrogen, sulphates, silica content and chlorophyll "a”) at most stations located along the abovementioned sector of the Danube River showed comparable values that have not exceeded those limits recommended by the reference standard. Instead, other variables (e.g., nitrite nitrogen, orthophosphates, turbidity and total suspended solids) showed concentration that exceeded those mentioned by the regulations in force, for some sampling points. The results of the assessment that characterized the Razim and Golovita lakes in terms of the physical and chemical properties revealed that the water quality is fairly good. Variables as water temperature, $\mathrm{pH}$, dissolved oxygen content, total dissolved solids, nitrate-nitrogen, sulphates, silica content and chlorophyll "a" were within desirable limits. Oppositely, the concentrations of electrical conductivity, nitrite nitrogen, orthophosphates, turbidity and total suspended solids exceeded the guideline values only in a few cases. The abnormal values encountered in few situations may be related to a wide range of local natural environmental circumstances, as well as anthropic factors. Presumably, the selfpurification ability and the dilution capacity of natural waters are key factors to successfully adapt to changing conditions influenced by natural or human-related activities. The outcomes obtained from the present study shall be useful in the future environmental assessment of the aquatic ecosystems in DDBR. Future assays with environmental samples are necessary to continue research in order to obtain an overall picture of the state of the water quality of the lower course of the Danube River, as well as other aquatic environments from the DDBR area. Everything that occurs in the lower course of the Danube River is the result of what occurs upstream, and, respectively the impact of the river water quality upon the aquatic environments from the DDBR area.

Acknowledgements. The research leading to these results was financed from the Ministry of Research and Innovation - MCI -Romanian Nucleu Programme 13N/2018 - Project PN 1816 0102.

\section{References}

ANZECC 2000 Guidelines - Australian and New Zealand Guidelines for Fresh and Marine Water Quality. Available from: http://www.mfe.govt.nz/freshwater/tools-and-guidelines/anzecc-2000 guidelines.

Banu, AC \& Rudescu, L 1957, 'Delta Dunarii-Evolutia, viata si bogatiile ei, Societatea pentru raspandirea Stiintei si Culturii, Bucuresti, pp. 66. In Romanian.

Chapman, D 1996, 'Water Quality Assessments - A Guide to Use of Biota, Sediments and Water in Environmental Monitoring - Second Edition',

Published on behalf of UNESCO, WHO, UNEP. E /FNSPON, University Press, Cambridge, London, UK, pp. 626. 


\section{INTERNATIONAL SYMPOSIUM "THE ENVIRONMENT AND THE INDUSTRY", SIMI 2018, PROCEEDINGS BOOK}

Close, M, Dan, R, Ball, A, Pirie, R, Savill, M \& Smith, Z 2008, 'Microbial groundwater quality and its health implications for a borderstrip irrigated dairy farm catchment, South Island, New Zealand', Journal of Water \& Health, vol. 6, no.1, pp. $83-98$.

DeZuane, J 1997, 'Handbook of Drinking Water Quality' (2nd ed.), John Wiley and Sons, USA, pp.592.

Dimitriu, RG, Oaie, Gh, Gomoiu, MT, Begun, T, Szobotka, S, Radan, SC \& Fulga, C 2008, 'An Interdisciplinary Characterization of the Geo-ecological State of the Razelm - Sinoie Lagoon Complex at the beginning of the $21^{\text {st }}$ Century', Geo-Eco-Marina, no.14, Supplement 1, pp. 69-74.

Dinu, I, Umgiesser, G, Bajo, M, de Pascalis, F, Stanica, A, Pop, C, Dimitriu, R, Nichersu, I \& Constantinescu, A 2015, 'Modelling of the response of the Razelm-Sinoie lagoon system to physical forcing', Geo-Eco-Marina, no. 21, pp. 5-18.

Doroftei, M \& Covaliov, S 2013, 'Handbook of the ... Danube Delta 2013', Guide for Field Staff of the Danube Delta Biosphere Reserve Administration and Environmental Guard, Danube Delta Technological Information Center (CITDD), Tulcea, Romania. In Romanian.

Egge, J \& Aksnes, D 1992, 'Silicate as regulating nutrient in phytoplankton competition', Marine ecology progress series, vol. 81, pp. 281-289.

European Union Council 2000, Directive 2000/60/EC of the European Parliament and of the Council of 23 October 2000 establishing a framework for Community action in the field of water policy, Official Journal of the European Communities, vol. 43, L327, pp. 1-73.

Johnson, DE, Bartlett, J \& Nash, LA 2007, 'Coastal lagoon habitat re-creation potential in Hampshire, England'. Marine Policy, vol. 31, pp. 599 - 606.

Hanganu, J, Dubyna, D, Zhmud, E, Grigoras, I, Menke, U, Drost, H, Stefan, N \& Sarbu, I 2002, 'Vegetation of the Biosphere Reserve „Danube Delta” - with Transboundary Vegetation Map on a 1: 150, 000 scale'. Danube Delta National Institute for Research and Development, Romania; M.G. Kholodny Institute of Botany and Danube Delta Biosphere Reserve, Ukraine and Institute for Inland Water Management and Waste Water Treatment (RIZA), The Netherlands. Lelystad: RIZA Rapport 2002.049

Huhta, A 2009, 'Decorative or Outrageous - The significance of the Common Reed (Phragmites australis) on water quality', Turku University of Applied Sciences - Comments, vol. 48, pp. 33.

Panin, N 1974, 'Evolution of the Danube Delta during the Holocene', Technical and Economic Studies of the Geological Institute, H-Series, Quaternary Geology, Bucharest, vol. 5, pp. 107-121.

Panin, N 1996, 'Impact of global changes on geo-environmental and coastal zone state of the Black Sea', Geo-Eco-Marina, no. 1, pp. 7-23.

Munteanu, I, Tuzlaru, C, Cioroiu, L, Vasilescu, G, Raicu, M, Bascau, F, Raileanu, G, Nitu, M \& Varzaru, E 2012, 'Report on the Danube Delta Biosphere 


\section{INTERNATIONAL SYMPOSIUM "THE ENVIRONMENT AND THE INDUSTRY", SIMI 2018, PROCEEDINGS BOOK}

Reserve - State of the Environment in 2012', Ministry of Environment and Climate Change. In Romanian.

OECD 1982, 'Eutrophication of Waters. Monitoring, Assessment and Control' Paris: Organisation for Economic Co-Operation and Development, (Publié en français sous le titre"Eutrophication des Eaux. Méthodes de Surveillance, d'Evaluation et de Lutte”), pp. 154. In French.

Order no. 161/2006 - Standard on surface water quality classification for determination of the ecological status of Water bodies, Annex C - Elements and physico-chemical quality standards in water, published in Romanian Official Monitor, part I, no. 511 bis, from $13^{\text {th }}$ of June, 2006. In Romanian.

Radan, S, Ganciu, A \& Strechie, C 2000, 'Overview of the Long-term Ecological Research performed by GeoEcoMar in the Danube Delta, Romania', in: Lajtha K. and Vanderbilt K., eds. 2000 - Cooperation in Long Term Ecological Research in Central and Eastern Europe, Oregon State University, Corvallis, OR, pp. 101-112

Romanescu, G 2009, 'The geomorphological evolution of the Razim-Sinoie barrier spit during the historical periods', Pontica, vol. 42, pp. 493-517.

Romanian Standard - STAS 6323 - 88 - Determination of turbidity

Ryding, SO \& Rast, W 1989. 'The Control of Eutrophication of Lakes and Reservoirs'. Parthenon Publishing Group, Lancaster, New Jersey, pp. 314

Sigg, L 2000, 'Redox Potential Measurements in Natural Waters: Significant Concepts and Problems'. In H.D. Schulz, W. R. Fischer, J. Bottcher and W.H.M. Duijinisveld (Eds) Redox: Fundamentals, Processes and Applications, Springer, Berlin, Germany

Spataru, AN 1990, 'Breakwaters for the Protection of Romanian Beaches', Coastal Engineering, vol. 14, pp. 129-146.

Stanica, A 2012, 'The Danube Delta. Back to nature through international cooperation. Chapter in Climate of Coastal Cooperation', R. Misdorp Editor. Publishers: Coastal \& Marine Union-EUCC (Leiden, the Netherlands).

Teodorescu-Leonte, R 1977, 'Le complexe Razelm - Sinoie un sistem typiquement saumatre', MAMBO Constanta. In Biologie des eaux saumatre de la Mer Noir, 213-234. In French.

Teodorescu-Leonte, R, Leonte, V, Dumitru, M \& Soileanu, B 1956, 'Observations on the Razelm - Sinoie complex during 1950-1952', The Annals of the Romanian Research Institute of Fisheries, vol. 1, pp. 1-50

U.S. Environmental Protection Agency 2007, 'National coastal condition report II', Publication 620/R-03/002, USEPA Office of Wetlands, Oceans and Watersheds, Washington, D.C., USA.

US EPA 1980, 'Clean lakes program guidance manual. Report No.: EPA-440/5-81003', United States Environmental Protection Agency (USEPA), Washington, DC., USA.

US EPA 2009, 816 - F - 09 - 004, May 2009. Available from: http://water.epa.gov/drink/contaminants/upload/mcl-2.pdf. 
Vespremeanu-Stroe, A, Constantinescu, S, Tatui, F \& Giosan, L Multi-decadal 2007, 'Evolution and North Atlantic Oscillation Influences on the Dynamics of the Danube Delta shoreline', Journal of Coastal Research, SI 50 (Proceedings of the 9th International Coastal Symposium), pp. 157-162.

Vespremeanu-Stroe, A, Preoteasa, L, Hanganu, D, Brown, T, Birzescu, I, Toms \& P Timar-Gabor, A 2013, 'The impact of the Late Holocene coastal changes on the rise and decay of the ancient city of Histria (Southern Danube delta)', Quaternary International, vol. 293, pp. 245-256.

WHO/UNEP, GEMS 1989, 'Global freshwater quality', Oxford, Alden Press

http://www.freedrinkingwater.com/water_quality/quality2/j-24-typical concentrations-for-silicates-ground-n-surface-waters.htm. [20 June 2018]. 